\title{
KOMPARATIF KURIKULUM DARUSSALAM DAN KURIKULUM 2013 TERHADAP MINAT BELAJAR SANTRI PADA PONDOK PESANTREN ASSUNNIYYAH TAMBARANGAN KECAMATAN TAPIN SELATAN KABUPATEN TAPIN
}

\author{
H. Mardiah \\ Sekolah Tinggi Ilmu Ekonomi Pancasetia Banjarmasin \\ Jl. A. Yani Km. 5.5 Banjarmasin \\ yaakusya@gmail.com
}

\begin{abstract}
This study aims to prove the simultaneous and partial effect of the Darussalam Curriculum and 2013 Curriculum on students' interest in learning; and prove which influence is dominant. This type of research used in this research is field research (field research) with a mix method approach. The results showed (1) Based on the simple linear regression test, it was found that both the 2013 Curriculum and the Darussalam Curriculum had an insignificant effect on the "students' interest in learning". (2) Based on the results of the multiple linear regression test, it is known that the two independent variables in this study simultaneously do not affect the dependent variable. (3) Based on the $\mathrm{R}$ value, it is known that the 2013 Curriculum is more dominant than the Darussalam Curriculum on the students' interest in learning. Based on qualitative data, it can also be concluded that learning with the 2013 curriculum is more influential than the Darussalam curriculum. This can be seen from the emergence of feelings of students in participating in learning activities using the two curricula, the involvement of students, interest in learning activities, attention, and benefits in learning. Where in these various aspects, the percentage of the 2013 curriculum application is more influential than the Darussalam curriculum.
\end{abstract}

Keyword: 2013 curriculum; Darussalam Curriculum; Interest in Learning Santri

Abstrak: Penelitian ini bertujuan untuk membuktikan pengaruh secara simultan dan parsial Kurikulum Darussalam dan Kurikulum 2013 terhadap minat belajar santri; dan membuktikan pengaruh mana yang dominan. Jenis Penelitian yang digunakan dalam penelitian ini adalah penelitian lapangan (field research) dengan pendekatan mix method. Hasil penelitian menunjukkan (1) Berdasarkan uji regresi linear sederhana diketahui bahwa baik Kurikulum 2013 maupun Kurikulum Darussalam memiliki pengaruh yang tidak signifikan terhadap "minat belajar santri". (2) Berdasarkan hasil uji regresi linear berganda diketahui bahwa kedua variabel bebas pada penelitian ini secara simultan tidak mempengaruhi variabel terikat. (3) Berdasarkan Nilai R diketahui bahwa Kurikulum 2013 lebih dominan pengaruhnya dibandingkan dengan Kurikulum Darussalam terhadap minat belajar santri. Berdasarkan data kualitatif juga dapat disimpulkan bahwa pembelajaran dengan kurikulum 2013 lebih besar pengaruhnya dibandingkan dengan kurikulum Darussalam. Hal ini dapat dilihat dari keterlibatan santri, ketertarikan pada kegiatan belajar, perhatian, dan manfaat dalam belajar. Di mana dalam berbagai aspek ini, persentase penerapan kurikulum 2013 lebih besar pengaruhnya dibandingkan dengan kurikulum Darussalam.

Kata Kunci: Kurikulum 2013; Kurikulum Darussalam; Minat Belajar Santri 


\section{Latar Belakang}

Kurikulum sebagai sebuah rencana yang disusun guna melancarkan proses pembelajaran di lembaga berada di bawah bimbingan, arahan dan tanggungjawab lembaga pendidikan tersebut dan juga para pendidik atau guru. Kegiatan kurikuler dan ekstrakurikuler yang bersifat formal maupun kegiatan yang tidak bersifat formal merupakan bagian kurikulum (Nasution, 2008: 5). Menurut Nana Sudjana, kurikulum adalah sebuah niat dan harapan dari lembaga pendidikan yang tertuang dalam bentuk program pendidikan dan rencana program yang diselenggarakan oleh guru di sekolah atau madrasah di mana dalam prosesnya melibatkan guru dan siswa (Sudjana, 2005: 5-7). Setiap lembaga pendidikan, termasuk Pondok Pesantren, meiliki kurikulum yang menuntut adanya subjek yang dibina dan subjek yang membina, dalam hal ini santri dan ustadz/ustadzah yang mengajar di pondok tersebut. Pondok pesantren mengembangkan kurikulum berupa program belajar bagi santri yang disusn secara sistematis, konsisten, dan logis. Pondok pesantren memberikan programprogram tersebut untuk mencapai tujun pendidikan. Pondok pesantren menjalankan program-program kegiatan dan memberikan pengalaman belajar kepada santri agar dapat mencapai hasil-hasil belajar yang diharapkan di mana sebelumnya telah diformulasikan melalui pengetahuan dan kegaiatan yang sistematis. Pondok pesantren memiliki peran besar dalam membantu perkembangan pribadi para santri dan kompetensi santri baik itu kompetensi agama, sosial maupun intelektual di bidang sains.

Pondok pesantren, sebagai sebuah lembaga pendidikan, sudah pasti memiliki kurikulum. Beberapa pondok pesantren memiliki dua jenis kurikulum untuk mencapai sasaran tujuan pendidikan nasional dan sasaran visi misi pondok tersebut. Pondok pesantren mengembangkan program belajar dan pembelajaran, serta merancang dan meingplementasikan atau melakukan operasional dari program-program yang telah dirancang tersebut. Dalam rangka mencapai tujuan tersebut, pondok pesantren memerlukan alat dan sarana proses belajar dan mengajar, sehingga nantinya para santri yang lulus dari pondok pesantren tersebut memiliki kompetensi yang hendak dikembangkan dan dibekali kepada para santri.

Pondok pesantren dalam mengembangkan kurikulum tidak hanya berfokus pada daftar subjek atau mata pelajaran yang diajarkan kepada para santri, namun juga mempertimbangkan berbagai program yang mampu mengembangkan segala bakat, potensi, dan kompetensi serta memberikan mengalaman belajar bagi para santri, yang nantinya pada akhirnya visi lembaga juga ikut tercapai. Hal ini sejalan dengan apa yang dirumuskan oleh Ronald C. Doll (1970:22) yang menyatakan bahwa: "... the commonly accepted definition of the curriculum has changed from content of course of study and list of subject and course to all the experiencewhich are offeres to learners unders the auspises or direction of the school".

Pondok pesantren, tidak terkecuali Pondok Pesantren Ma'arif Assunniyyah juga telah mengembangkan dua jenis kurikulum yang diimplementasikan di pondok pesantren tersebut, yakni kurikulum pondok dan kurikulum sekolah. Kurikulum pondok yang disebut sebagai kurikulum darussalam difokuskan untuk mencapai visi pondok dan kurikulum sekolah yakni yang sekarang ini telah mengimplementasikan kurikulum 2013 di mana sebelumnya pondok ini menggunakan Kurikulum berbasis Kompentensi (KBK) dan Kurikulum Tingkat Satuan Pendidikan (KTSP). UU RI No 20 Tahun 2003 tentang Sistem Pendidika Nasional Pasal 1 ayat 19 menyebutkan bahwa kurikulum merupakan seperangkat rencana dan pengaturan mengenai tujuan, isi, tambahan pelajaran serta cara yang digunakan sebagai pedoman penyelenggaraan kegiatan pembelajaran untuk mencapai tujuan pendidikan tertentu. Oleh karenanya Pondok Pesantren Ma'arif 
Assunniyyah mengimplementasikan kedua jenis kurikulum tersebut di lembaganya.

Fungsi dan peranan kurikulum di Pondok Pesantren Ma'arif Assunniyyah adalah, sebagai mana yang diungkapkan Beauchamp (1968: 6), sebagai rencana pendidikan. "..a curriculum is a written document which may contain many ingredients, but basically it is the plant for education of pupils during their enrollment in given school"..

Artinya, Pondok Pesantren Ma'arif Assunniyyah memiliki kedua jenis kurikulum tersebut sebagai rencana yang memberikan pegangan dan pedoman bagi lembaga (Sukmadinata, 2005: 4-5). dalam pelaksanaan proses belajar mengajar. Kurikulum di Pondok Pesantren Ma'arif Assunniyyah tidak hanya sekedar sebagai acuan bidang studi yang diajarkan, namun juga acuan rencana pengajaran dalam sistem kurikulum (Beauchamp, 1976: 5859) yang merupakan bagian dari sistem pondok pesantren. Di mana nantinya kedua jenis kurikulum yang diterapkan di Pondok Pesantren Ma'arif Assunniyyah tersebut dapat merangkum segala pengalaman santri di bawah bimbingan dan arahan pendidik (ustadz/ustadzah). Caswel dan Chambel menyebutkan bahwa ..to be composed of all experience children have a under the guidance of teacher. Dalam menyusun kurikulum yang diterapkan, pondok pesantren tersebut memperhatikan ketentuan yang diatur oleh pemerintah mengenai kurikulum. Yakni yang tertuang dalam UU Nomor 20 Tahun 2003 pasal 36 ayat (3) yang menyebutkan bahwa kurikulum hendaknya disusun sesuai dengan jenjang dan jenis pendidikan dalam kerangka Negara Kesatuan Republik Indonesia dengan memperhatikan: peningkatan iman dan takwa, akhlak mulia, kecerdasan, potensi, dan minat peserta didik, kemajmemukan potensi daerah dan lingkungan daerah, selain itu juga diharapkan untuk memperhatikan tuntutan pembangunan daerah dan nasional, dunia kerja, perkembangan ilmu pengetahuan, teknologi, dan seni; agama; dinamika perkembangan global; dan ersatuan nasional dan nilai-nilai kebangsaan.

Kurikulum ini memiliki fungsi yang penting dalam perkembangan Pondok Pesantren Ma'arif Assunniyyah, di mana fungsinya sebagai pedoman yang mengatur kegiatan dan lingkungan yang berlangsung untuk proses belajar dan mengajar. Beberapa elemen penting yang berkaitan dengan program dan kegiatan yang diimplementasikan di Pondok Pesantren Ma'arif Assunniyyah dalam kerangka target kurikulumnya adalah meberdayakan dan memantapkan perjuangan untuk menegakkan nilai-nilai keislaman dalam persaingan dunia yang semakin maju, global, dan berbasis multidimensi dalam sistem informasi dan komunikasi. Beradasarkan hasil observasi awal di lapangan di ketahui bahwa Pondok Pesantren Ma'arif Assunniyyah menyusun sebuah program terkait kaderisasi santri / santriwati yang mempunyai prestasi, yakni dengan membina dan bekerjasama dengan orang tua asuh dan pihak yang peduli terhadap pendidikan. Selain itu, pondok pesantren ini juga selalu berupaya mengembangkan sistem pengajaran dan pendidikan di pondok pesantren dengan dilihatnya perubahan perubahan dan perkembangan kurikulum yang senantiasa diikuti oleh pondok pesantren. Pondok Pesantren Ma'arif Assunniyyah juga melaksanakan program terkait pembangunan dan perluasan Pondok Pesantren serta pengembangan sarana / prasarana pendidikan. Hal ini sebagi upaya dari pondok pesantren untuk memaksimalkan proses pembelajaran yang bermutu. Selain itu, berdasarkan hasil observasi juga diketahui bahwa Pondok Pesantren Ma'arif Assunniyyah juga memberdayakan masyarakat melalui Majlis Ta'lim, da'wah umum hal ini guna memperoleh dukungan moril dan material dalam keberlangsungan pondok pesantren. Upaya lain yang dilakukan Pondok Pesantren Ma'asri Assunniyyah dalam implementasi kurikulumnya adalah menjalin kerjasama dengan Pemerintah, Instansi yang terkait dan para pengembang 
modal serta pihak - pihak yang mempunyai kepedulian terhadap kemajuan dan perkembangan pendidikan di Pondok Pesantren.

Berdasarkan hasil wawancara dengan guru (ustadz dan ustadzah) yang mengajar di Pondok Pesantren Ma'arif Assunniyyah Tambarangan diketahui bahwa selama proses pelajaran berlangsung di sekolah (Madrasah Stanawiyah) santri mengikuti proses belajar sesuai jadwal yang telah ditentukan. Klasifikasi pemisahan ruang kelas berdasarkan gender ditetapkan di madrasah yang dikelola oleh pondok pesantren ini guna menjalankan syariat di mana laki-laki dan perempuan yang bukan muhrim haruslah selalu terjaga keimanan dan ketakwaannya. Menurut salah satu guru belum pernah ada santri ataupun komite orangtua yang mempermasalahkan kondisi kelas berbasis gender seperti ini. Karena memang pada dasarnya lembaga ini memiliki tujuan untuk mendidik para santri / santriwati agar menjadi manusia yang bertaqwa, berahklaq mulia dan mengamalkan ajaran agama dalam kehidupan sehari - hari serta menjadi warga negara yang baik. Menurut guru mata pelajaran akidah akhlak di madrasah stanawiyah, santri selalu mengerjakan tugas-tugas yang diberikan dan hafalan hafalan yang diberikan, menurutnya sangat jarang menemukan santri yang tidak melaksanakan tugasnya.

Selain itu berdasarkan hasil pengamatan dalam proses pembelajaran di kegiatan sore diketahui bahwa para santri terlihat kurang bersemangat dalam mempelajari kitab kuning, meskipun hampir semua santri hadir dalam kegiatan dan membawa bahan belajar buku dan kitab yang mereka perlukan. Beberapa santri lebih terlihat pasif dalam proses pembelajaran dan ustadz yang menyampaikan materi sangat fokus dalam menyelesaikan bahan materi. Di satu sisi, interaksi dengan para santri sangat kurang. Menurut beberapa santri menyatakan bahwa mereka belum mampu membaca kitab tersebut tanpa ada bimbingan, oleh karenanya mereka lebih memilih diam mendengarkan ustadz ketimbang membahas atau mengajukan pertanyaan pada materi yang mereka kurang pahami. Meskipun pada dasarnya para santri belajar kitab-kitab tersebut dalam tiga kategori, yakni kategori santri yang belajar kitabkitab dasar, kitab kitab level menengah dan kitab-kitab besar yang membutuhkan usaha lebih keras untuk mempelajari. Di mana semua kitab tersebut diselesaikan dalam 23 tahun akademik. Para santri menyatakan bahwa harga kitab yang relatif mahal bagi mereka juga menyebabkan mereka terkendala dalam membaca ulang isi kitab yang telah dipelajajari tersebut.

Berdasarkan hasil wawancara dengan Pimpinan Pondok Pesantren Ma'arif Assunniyyah diketahui bahwa jumlah santri yang masuk pada tahun ajaran 2019/2020 sekitar 563 orang, hal ini berbeda dengan tahun-tahun sebelumnya di mana jumlah santri yang masuk hanya sekitar 210 orang. Meskipun jumlah santri yang masuk untuk belajar di pondok pesantren Ma'arif Assunniyyah meningkat setiap tahunnya, namun sungguh disesalkan bahwa jumlah santri lulusan setiap tahun tidak seimbang dengan jumlah santri yang masuk. Menurut Staf administrasi Pondok Pesantren Ma'arif Assunniyyah Tambarangan sekitar 30\% dari total santri berhenti bersekolah di Pondok Pesantren Ma'arif Assunniyah setiap tahunnya, alasan para santri tidak menyelesaikan studinya di pondok tersebut adalah karena putus sekolah baik karena faktor kurang dukungan motivasi dari keluarga, alasan menikah, psikis yang lemah, dan transfer ke sekolah umum. Kondisi ini sangat memprihatinkan bagi pihak pondok di mana mereka belum menemukan permasalahan yang pasti dari banyaknya santri yang berhenti, selain itu solusi yang tepat untuk menghadapi permasalahan tersebut yang digali secara ilmiah belum pernah dilakukan di lembaga tersebut. Data mengenai putus sekolah di pondok ini belum pernah digali secara ilmiah, hanya berupa catatan-catatan alasan berhenti setiap santri yang belum pernah dicarikan solusinya. Hemat peneliti, selain motivasi 
ini juga tentu berkaitan dengan aktivitas dan kegiatan yang diselenggarakan di pondok tersebut yang seharusnya mampu meningkatkan minat santri untuk selalu belajar dengan giat di pondok dan memiliki motivasi yang kuat untuk menyelesaikan studinya di pondok tersebut.

Oleh karenanya dengan melihat dan merujuk kondisi tersebut, maka peneliti tertarik untukmenggali lebih lanjut konteks keterkaitan antara minat belajar santri terhadap implementasi kurikulum di Pondok Pesantren Ma'arif Assunniyyah Tambarangan Kabupaten Tapin, baik kurikulum Darussalam dan juga kurikulum 2013 sangat urgen untuk dikaji. Berdasarkan hal tersebut, peneliti sangat tertarik untuk melakukan penelitian guna mendeskripsikan kurikulum darussalam dan kurikulum 2013 Pondok Pesantren Ma'arif Assunniyyah Tambarangan Kabupaten Tapin, dan menguji pengaruh keduanya tehadap minat belajar santri di Pondok tersebut dalam penelitian yang berjudul: Komparatif Kurikulum Darussalam dan Kurikulum 2013 terhadap Minat Belajar Santri pada Pondok Pesantren Ma'arif Assunniyyah Tambarangan Kecamatan Tapin Selatan Kabupaten Tapin.

\section{Studi Literatur}

Pada dasarnya telah banyak penelitian terdahulu yang melakukan penelitian terkait minat belajar di antaranya penelitian yang dilakukan oleh Siti Nurhasanah dan A. Sobandi (2016) yang menunjukkan bahwa hasil belajar siswa dapat ditingkatkan melalui peningkatan minat belajar siswa, semakin baik minat belajar siswa akan berdampak pada hasil belajar siswa yang semakin baik. Selain itu juga ada penelitian yang dilakukan oleh I Made Putrayasa, Syahruddin, dan I Gede Margunayasa (2014) yang menunjukkan bahwa model pembelajaran discovery learning dan minat belajar berpengaruh terhadap hasil belajar siswa. Selain itu juga ada penelitian yang dilakukan oleh Keke T Aritonang (2008) yang menggambarkan bahwa Faktor utama yang mempengaruhi minat dan motivasi belajar adalah cara mengajar guru, karakter guru, suasana kelas tenang dan nyaman, dan fasilitas belajar yang digunakan. Selaras dengan temuan yang diperoleh, penelitian ini memberikan saran operasional bagaimana meningkatkan minat dan motivasi belajar siswa. Namun, dalam jangkauan lieterature dan kajian pustaka yang telah peneliti lakukan, belum pernah ditemukan penelitian mengenali keterkaitan antara kurikulum 2013 dan kurikulum Darussalam yang diimpelementasikan di sebuahpondok dan dilihat perbandingannya yang mana lebih dominan dalam mempengaruhi minat belajar santri. Beberapa hasil penelitian terdahuludijadikan dasar dalam menganalisis dan membahas dalam hasil data yang dikumpulkan dalam penelitian.

\section{Kurikulum}

Secara terminologi, kurikulum dapat dimaknai sebagai semua ruang pembelajaran terencana yang diberikan lembaga pendidikan kepada siswa dan juga pengalaman yang dapat dinikmati oleh siswa ketika sebuah kurikuluditerapkan (Rosyada, 2004: 26). Wina Sanjaya (2005: 2) memaparkan bahwa istilah kurikulum sebenarnya dapat dimakna dalam tiga konsep, yakni:

a. Kurikulum sebagai Rangkaian Mata Pelajaran; Sejumlah mata pelajaran harus dikuasai peserta didik dalam proses pembelajaran yang terencana, dan biasanya menggunakan penilaian ahli bidang studi untuk menentukan mata pelajaran apa yang perlu diajarkan kepada siswa, tingkat kesulitan yang harus dikuasai siswa, minat siswa, strategi pembelajaran yang dipercaya dapat menjadikan siswa mampu menguasai materi pelajaran, serta urutan bahan pelajaran yang akan disampaikan kepada siswa.

b. Kurikulum sebagai Pengalaman Belajar; Seluruh program yang diselenggarakan lembaga pendidikan dan kegiatan yang dilakukan oleh siswa baik ketika berada di dalam sekolah maupun kegiatan di luar sekolah. 
c. Kurikulum sebagai Program Belajar; Kurikulum memuat tujuan yang harus ditempuh oleh siswa beserta alat evaluasi untuk menentukan keberhasilan pencapaian tujuan.

Kurikulum bermakna sebagai semua pengalaman yang dilakukan oleh siswa, di mana semua kegiatan tersebut telah dirancang, didesain, diberikan bimbingan oleh guru, dan dipertanggungjawabkan oleh lembaga pendidikan (Sukmadinata, 2003: 18). Kurikulum juga dapat diartikan sebagai program pendidikan yang disediakan oleh lembaga pendidikan bagi siswa (Hamalik, 2010: 10). Kurikulum sebagai alat pendidikan memiliki fungsi, di antaranya: (1) Fungsi penyesuaian (Adaptive function); (2) Fungsi Integrasi atau (integrating function); artinya kurikulum sebagai alat pendidikan yang dapat menghasilkan pribadi yang dapat dibutuhkan dan berintegrasi dengan masyarakat. (3) Fungsi Diferensisi (the diferentiating function); (4) Fungsi persiapan (the propaeduetic function); (5) Fungsi pemilihan (the selective function); (6) Fungsi pemilihan (the selective function); (7) Fungsi diagnotik (the diagnostic function) (Tim Pengembang MKDP Kurikulum dan Pembelajaran, Kurikulum dan Pembelajaran, 2011: 9).

\section{Kurikulum 2013}

Kurikulum 2013, merupakan salah satu kurikulum yang dikembangkan oleh pemerintah Indonesia yang telah dikaji dan ditelaah dengan pijakan landasan filosofis, psikologis, sosiologis, ilmu pengetahuan dan teknologi. Kurikulum 2013 merupakan salah satu produk yang dihasilkan oleh Pemerintah Indonesia, di mana sebelumnya dikembangkan dan dipergunakan di Indonesia seperti Rencana pelajaran 1947, Kurikulum 1952, Kurikulum 1964, Kurikulum 1968, Kurikulum 1975, Kurikulum 1984, Kurikulum 1994, Kurikulum berbasis Kompetensi tahun 2004, Kurikulum Tingkat Satuan Pendidikan tahun 2006, dan yang terakhir Kurikulum 2013 (Hidayat, 2013: 10). $\begin{array}{ccc}\text { Kurikulum } & 2013 & \text { telah } \\ \text { dikembangkan melalui } & \text { proses } & \text { yang }\end{array}$ pnajang, di mana pemerintah telah melakukan dialog tatap muka, dialog virtual, dan tulisan. Hasil dari kajian tersebut menunjukkan adanya hasil positif yang dapat memperkuat pemerintah untuk melakukan pengembangan Kurikulum 2013 (Tertuang dalam Peraturan Pemerintah RI Nomor 32 Tahun 2013, Perubahan atas Peraturan Pemerintah Nomor 19 Tahun 2005 tentang Standar Nasional Pendidikan) Adapun prinsip yang dijadikan pedoman dalam pengembangan Kurikulum 2013 sama seperti prinsip penyusunan Kurikulum Tingkat Satuan pendidikan (Tertuang dalam Peraturan Menteri Pendidikan dan kebudayaan atau permendikbud Nomor 81A tahun 2013), yakni:

a. Kurikulum 2013 menjadikan peningkatan iman, takwa, dan akhlak mulia sebagai landasa. Tiga unsur ini menjadi dasar pembentukan kepribadian siswa secara utuh.

b. Kebutuhan kompetensi masa depan, di antaranya kemampuan siswa dalam berkomunikasi, berfikir kritis, dan kreatif dengan mempertimbangkan nilai dan moral Pancasila agar menajdi warga negara yangd emokratis dan bertanggungjawab, toleran dalam keberagaman, mampu hidup dalam masyarakat global, memiliki kemampuan, minat luas dalam kehidupan dan siap unuk bekerja, cerdas sesuai minat bakatnya dan peduli tehadap lingkungan. Kurikulum 2013 harus mampu menjawab tantangan tersebut sehingga perlu pengembangan lebih lanjut dalam proses pembelajaran.

c. Peningkatan kecerdasan, potensi, dan minat yang sesuai dengan perkembangan dan kemampuan siswa, di mana proses pendidikan dirancang dengan sistematis dan holistik yang memungkinkan potensi diri siswa baik afektif, kognitif, maupun psikomotorik berkembang secara optimal. 
d. Kurikulum 2013 memperhatikan aspek keragaman potensi dan karakteristik daerah dan lingkungan.

e. Kurikulum 2013 menjadi media pengikat dan pengembang keutuhan bangsa dan mengedepankan wawasan nasional sesuai dengan tuntutan pembangunan daerah dan nasional.

f. Kurikulum 2013 memperhatikan aspek tuntutan dunia kerja, siswa dikembangkan agar tumbuh menjadi siswa yang memiliki kepribadian yang cakap dan berjiwa kewirausahaan, serta perkembangan ilmu pengetahuan, teknologi, dan seni.

g. Kurikulum 2013 dikembangkan dengan unsur agama, di mana program utamanya adalah mendukung peningkatan iman, takwa, serta akhlak mulia dan memelihara toleransi dan kerukunan umat beragama.

h. Kurikulum 2013 mendukung kegiatan proses pendidikan yang mampu mengembangkan individu agar mampu bersaing dan kurikulum 2013 berupaya mengikuti perkembangan global. Kurikulum ini dikembangkan dengan landasan persatuan nasional dan nilai-nilai kebangsaan.

i. Kurikulum 2013 dikembangkan dengan landasan kondisi sosial budaya masyarakat setempat, dan diarahkan pada pengembangan sikap dan perilaku yang berkeadilan dengan memperhatikan kesetaraan gender.

j. Kurikulum 2013 dikembangkans esuai dengan kondisi dan ciri khas pendidikan.

\section{Kurikulum Pondok}

Kurikulum, seperti yang diungkapkan oleh Omar Hamalik (2010: 10), merupakan program pendidikan yang disediakan oleh lembaga pendidikan menjadi asas bagi siswa melakukan kegiatan belajar. Sehingga perkembangan dan pertunbuhan kemampuan siswa sesuai dengan tujuan pendidikan yang telah ditetapkan sebelumnya. Dalm hal ini Pondok Pesantren telah mengembangkan serangkaian program dan kegiatan untuk santri agar dapat mencapai sasaran atau tujuan dari proses pembelajaran. Dalam hal ini kurikulum yang dikembangkan oleh Pondok Pesantren merupakan bagian paling fundamental dari sebuah lembaga pendidikan keagamaan yang menggambarkan secara sesungguhnya proses pendidikan.

Kurikulum di lembaga pendidikan sejogjanya juga dikembangkan dengan rancanagn kurikulum, seperti:

a. Rancangan tujuan kurikulum; di mana kurikulum sebagai tujuan dari program pendidikan yang diberikan kepada ssiswa (Anwar, 2003: 47).

b. Rancangan materi kurikulum (Zainal Arifin, 2012: 88-90), di mana kriteria pondok pesantren dalam memilih isi kurikulum mempertimbangkan beberapa hal, seperti: Isi materi sesuai dengan tujuan yang ingin dicapai; Sesuai dengan tingkat perkembangan santri; Bermanfaat bagi siswa/santri, masyarakat, bangsa, dan negara baik untuk masa sekarang maupun masa yang akan datang.

c. Rancangan Strategi Pelaksanaan Kurikulum (Zaini Muhammad, 2009: 86); dalam hal ini yang berkaitan dengan proses pendidikan, pendekatan pembelajaran yang digunakan, tingkat dan jenjang pendidikan, proses belajar mengajar, bimbingan penyuluhan, administrai dan supervisi pendidikan, sarana kurikuler, evaluasi dan proses penilaian.

d. Rancangan Evaluasi Kurikulum; baik evaluasi hasil belajar seperti evaluasi formatif dan evaluasi sumatif, dan juga evaluasi proses pembelajaran itu sendiri.

Secara garis besar, implementasi kurikulum mencakup tiga kegiatan pokok (Mulyasa , 2003: 93-103), tidak terkecuali yang juga dikembangkan di pondok pesantren, yakni meliputi: (1) 
Pengembangan program; program tahunan, program semester, program mingguan dan harian, serta program pengayaan dan juga remidial. Selain itu juga ada program bimbingan dan konseling pendidikan. (2) Pelaksanaan pembelajaran, seperti tes awal, proses, dan tes akhir. (3) Evalausi hasil belajar, seperti kaitannya dengan penilaian kelas, tes kemampuan dasar, penilaian akhir satuan pendidikan, benchmarking, dan penilaian program.

Kurikulum di Pondok Pesantren, tidak lepas dengan definisi pesantren itu sendiri. Soegarda Poerbakawatja yang dikutip oleh Haidar Putra Daulay, mengatakan pesantren berasal dari kata santri yaitu seseorang yang belajar agama Islam, sehingga dengan demikian pesantren mempunyai arti, tempat orang berkumpul untuk belajar agama Islam. Ada juga yang mengartikan pesantren adalah suatu lembaga pendidikan Islam Indonesia yang bersifat "tradisional" untuk mendalami ilmu tentang agama Islam dan mengamalkannya sebagai pedoman hidup keseharian (Daulay, 2004: 26-27). Di mana pondok pesantren yang merupakan sebuah lembaga non formal mempunyai beberapa tujuan diantaranya sebagai tempat pembelajaran agama islam, sebagai tempat pengembangan kebudayaan islam, dan sebagai sarana pengkaderan ulama dan cendekiawan muslim. Para Pendidik di Pondok Pesantren ialah santri yang lebih senior, yang telah menyelesaikan proses mengaji mereka di pondok tersebut, atau di pondok lain, sedangkan metode mngajar yang digunakan masih ebrsifat metode ceramah, di mana pengajar memberikan penjabaran tentang suatu materi kemudian dijelaskan. Selain iu metode yang sering dipergunakan adalah metode tanya jawab , di maan selama proses belajar mengajar bertanya memegang peranan penting guna meningkatkan pertisipasi santri dalam kegiatan belajar mengajar. Kegiatan tanya jawab disinyalir mampu membangkitkan minat dan rasa ingin tahu santri terhadap masalah yang sedang dibicarakan.

\section{Minat Belajar}

Minat adalah kecenderungan yang menetap dalam subjek untuk merasa tertarik pada bidang atau hal tertentu dan merasa senang berkecimpung dalam bidang itu (Winkel, 1984: 30). Hal ini sama seperti pendapat Slamento yang menyatakan bahwa Minat adalah kecenderungan jiwa yang tetap untuk memperhatikan dan mengenang beberapa aktivitas atau kegiatan. Seseorang yang berminat terhadap suatu aktivitas dan memperhatikan itu secara konsisten dengan rasa senang (Slameto, 1995: 20). Dilihat dari arti dasar katanya, Kata minat berasal dari bahasa inggris interes yang berarti kesukaan, perhatian (kecenderungan hati pada sesuatu), keinginan. Jadi arti minat berarti perhatian, kesukaan (kecenderungan) hati kepada suatu kegiatan (Poerwodarminto, 1984: 1134). Minat adalah suatu rasa lebih suka dan rasa ketrikatan pada suatu hal atau aktivitas tanpa ada yang menyuruh (Djamarah, 2008: 191) atau diistilah lain, minat adalah keinginan yang terus menerus untuk memperhatikan atau melakukan sesuatu. Minat dapat menimbulkan semangat dalam melakukan kegiatan agar tujuan dari pada kegiatan tersebut dapat tercapai. Dan semangat yang ada itu merupakan modal utama bagi setiap individu untuk malakukan suatu kegiatan (Dirjen Dikdasmen Depdikbud, 1997: 6). Jadi dapat difahami bahwa minat belajar merupakan salah satu bentuk keaktifan seseorang yang mendorong untuk melakukan serangkaian kegiatan jiwa dan raga untuk memperoleh suatu perubahan tingkah laku sebagai hasil dari pengalaman individu dalam interaksi dalam lingkungannya yang menyangkut kognitif, afektif, dan psikomotorik.

\section{Indikator Minat Belajar}

Minat belajar yang besar cenderung menghasilkan prestasi yang tinggi, sebaliknya minat belajar yang kurang akan menghasilkan prestasi yang rendah (Dalyono, 2005: 56-57). Ada beberapa indikator siswa yang memiliki minat belajar yang tinggi. Hal ini dapat dikenali melalui 
proses belajar di kelas maupun di rumah, di antaranya: (1) Perasaan senang; Seorang siswa yang memiliki perasaan senang atau suka terhadap pelajaran, maka ia harus terus mempelajari ilmu yang berhubungan dengan mata pelajaran tersebut. Sama sekali tidak ada perasaan terpaksa untuk mempelajari bidang tersebut. (2) Perhatian dalam belajar; Adanya perhatian juga menjadi salah satu indikator minat. Perhatian merupakan konsentrasi atau aktifitas jiwa kita terhadap pengamatan, pengertian, dan sebagainya dengan mengesampingkan yang lain dari pada itu. Seseorang yang memiliki minat pada objek tertentu maka dengan sendirinya dia akan memperhatikan objek maka ia berusaha untuk memperhatikan penjelasan dari gurunya. (3)Bahan pelajaran dan sikap guru yang menarik; Tidak semua siswa menyukai suatu bidang studi pelajaran karena faktor minatnya sendiri. Ada yang mengembangkan minatnya terhadap bidang pelajaran tersebut karena pengaruh dari gurunya, teman sekelas, bahan pelajaran yang menarik. Walaupun demikian lamakelamaan jika siswa mampu mengembangkan minatnya yang kuat terhadap mata pelajaran niscaya ia bisa memperoleh prestasi yang berhasil sekalipun ia tergolong siswa yang berkemampuan rata-rata. (4)Manfaat dan Fungsi Mata Pelajaran; Selain adanya perasaan senang, perhatian dalam belajar dan juga bahan pelajaran serta sikap guru yang menarik. Adanya manfaat dan fungsi pelajaran juga merupakan salah satu indikator minat. Karena setiap pelajaran mempunyai manfaat dan fungsinya.

Selain itu, secara sederhana menurut Slameto (2013: 180) beberapa indikator minat belajar yaitu sebagai berikut (1) Perasaan senang, (2) Ketertarikan siswa, (3) Perhatian dan (4) Keterlibatan siswa. Masing-masing indikator tersebut sebagai berikut: (1) Perasaan Senang;Seorang siswa yang memiliki perasaan senang atau suka terhadap suatu mata pelajaran, maka siswa tersebut akan terus mempelajari ilmu yang disenanginya. Tidak ada perasaan terpaksa pada siswa untuk mempelajari bidang tersebut. (2) Ketertarikan Siswa; Berhubungan dengan daya gerak yang mendorong untuk cenderung merasa tertarik pada orang, benda, kegiatan atau bisa berupa pengalaman afektif yang dirangsang oleh kegiatan itu sendiri. (3) Perhatian Siswa; Perhatian merupakan konsentrasi atau aktivitas jiwa terhadap pengamatan dan pengertian, dengan mengesampingkan yang lain dari pada itu. Siswa yang memiliki minat pada objek tertentu, dengan sendirinya akan memperhatikan objek tersebut.

Keterlibatan siswa; Siswa terlibat aktif selama proses belajar menunjukkan minatnya. Dari beberapa pendapat para ahli di atas, dapat diketahui indikator adanya minat pada seseorang dari beberapa hal, antara lain: adanya perasaan senang, adanya peningkatan perhatian, adanya ketertarikan pada pelajaran tersebut yang merupakan akibat dari rasa senang dan perhatian.

\section{Faktor Yang Mempengaruhi Minat Belajar}

Minat adalah keinginan terhadap sesuatu tanpa ada paksaan. Dalam minat belajar seorang siswa memiliki faktorfaktor yang mempengaruhi minat belajar yang berbeda-beda, menurut syah membedakannya menjadi tiga macam (Muhibbin, 2003: 132), yaitu:

a. Faktor internal; faktor dari dalam diri siswa yang meliputi dua aspek, yakni : 1) aspek fisiologis; kondisi jasmani dan tegangan otot (tonus) yang menandai tingkat kebugaran tubuh siswa, hal ini dapat mempengaruhi semangat dan intensitas siswa dalam pembelajaran. 2) aspek psikologis; aspek psikologis merupakan aspek dari dalam diri siswa yang terdiri dari, intelegensi, bakat siswa, sikap siswa, minat siswa, motivasi siswa.

b. Faktor Eksternal Siswa; Faktor eksternal terdiri dari dua macam, yaitu faktor lingkungan sosial dan faktor lingkungan nonsosial. Lingkungan Sosial yaitu lingkungan sosial terdiri dari sekolah, keluarga, masyarakat dan teman sekelas, dan Lingkungan 
Nonsosial adalah lingkungan sosial terdiri dari gedung sekolah dan letaknya, faktor materi pelajaran, waktu belajar, keadaan rumah tempat tinggal, alat-alat belajar.

c. Faktor Pendekatan Belajar; Faktor pendekatan belajar yaitu segala cara atau strategi yang digunakan siswa dalam menunjang efektivitas dan efisiensi proses pembelajaran materi tertentu (Muhibbin, 2003: 132-139).

\section{Metode Penelitian}

Penelitian ini dilaksanakan di Pondok Pesantrena Ma'arif Assunniyyah Tambarangan Kecamatan Tapin Selatan Kabupaten Tapin. Penelitian ini berupaya untuk membuktikan apakah Kurikulum Darussalam dan Kurikulum 2013 berpengaruh secara simultan dan parsial terhadap minat belajar santri di Pondok Pesantren Ma'arif Assunniyyah Tambarangan Kecamatan Tapin Selatan Kabupaten Tapin. Serta dalam penelitian ini, peneliti juga akan membandingkan kurikulum manakah di antara Kurikulum Darussalam dan Kurikulum 2013 yang berpengaruh paling dominan terhadap minat belajar santri di Pondok Pesantren Ma'arif Assunniyyah Tambarangan Kecamatan Tapin Selatan Kabupaten Tapin.

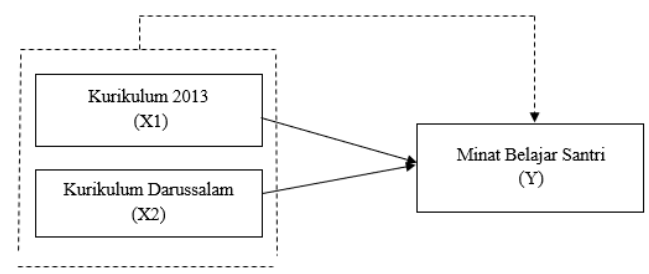

Gambar 1 Kerangka Konseptual Data diolah (2020)

Keterangan:

Simultan

: Pengaruh secara

\section{$\longrightarrow \quad$ : Pengaruh secara}

Parsial

1. Variabel Independen (variabel bebas)

Yaitu variabel yang merupakan rangsangan untuk mempengaruhi variabel lain.
Yang menjadi variabel bebas adalah:

a. Kurikulum 2013 (X1)

b. Kurikulum Darussalam (X2)

2. Variabel Dependen (variabel terikat)

Yaitu variabel yang merupakan hasil dari perilaku yang di rangsang. Dalam penelitian ini yang menjadi variabel terikat adalah minat belajar santri (Y).

Dalam penelitian ini peneliti memiliki kerangka konseptual yakni santri merupakan subjek belajar. Selama ini penelitian mengenai subjek belajar santri telah banyak dilakukan, khususnya mengenai minat belajar santri. Hanya saja, secara garis besar kajian mengenai minat santri ataupun minat siswa di madrasah hanya dilihat dari segi pengaruhnya terhadap hasil belajarnya atau prestasi belajarnya di sekolah. Jika seorang santri tidak berminat untuk mempelajari sesuatu tidak dapat diharapkan bahwa dia akan berhasil dengan baik dalam mempelajari hal tersebut, sebaliknya jika santri mempelajari sesuatu dengan penuh nikmat, maka dapat diharapkan bahwa hasilnya akan lebih baik. Penelitian terdahulu banyak yang menunjukkan bahwa faktor yang mempengaruhi tingginya minat belajar adalah perhatian orang tua, metode yang digunakan guru, lingkungan sekolah, lingkungan keluarga, dan latar belakang pendidikan guru secara individu. Namun, belum ditemukan adanya penelitian yang menunjukkan bahwa kurikulum yang diterapkan oleh lembaga pendidikan bisa saja memberikan andil yang cukup besar dalam meningkatkan minat belajar santri. Kurikulum merupakan komponen pokok dalam pendidikan, karena kurikulum merupakan kompas penunjuk arah hendak ke mana santri sebagai peserta didik diarahkan. Kurikulum dipandang sebagai program pendidikan yang direncanakan dan dilaksanakan guna mencapai tujuan. Kurikulum di pondok pesantren memegang kedudukan sentral dan fleksibel dalam keseluruhan proses pembelajaran. Di Pondok Pesantren Ma'arif Assunniyyah 
Tambarangan Kecamatan Tapin Selatan Kabupaten Tapin menggunakan dua jenis kurikulum, yakni Kurikulum 2013 dan Kurikulum Darussalam. Oleh karenanya penelitian ini sangat penting untuk memberikan gambaran yang rinci mengenai implementasi kedua kurikulum tersebut dan bagaimana perbandingan pengaruh kedua kurikulum.

Hipotesis dalam penelitian ini dimaknai sebagai jawaban sementara yang diajukan oleh peneliti. Secara statistik, hipotesis dalam penelitian ini akan dijabarkan dalam pernyataan mengenai keadaan parameter yang akan diujikan oleh peneliti dengan menggunakan sampel penelitian. Hipotesis ini nantinya menjadi dasar pijakan peneliti dalam menunjukkan data yang dapat digunakan oleh peneliti dalam menafsirkan data, yakni terkait pengaruh kurikulum darussalam dan kurikulum 2013 terhadap minat belajar santri di Pondok Pesantren Ma'arif Assunniyyah Tambarangan. Hipotesis dalam penelitian ini adalah:

1. Kurikulum Darussalam dan Kurikulum 2013 berpengaruh secara simultan terhadap minat belajar santri di Pondok Pesantren Ma'arif Assunniyyah Tambarangan Kecamatan Tapin Selatan Kabupaten Tapin.

2. Kurikulum Darussalam dan Kurikulum 2013 berpengaruh secara parsial terhadap minat belajar santri di Pondok Pesantren Ma'arif Assunniyyah Tambarangan Kecamatan Tapin Selatan Kabupaten Tapin.

3. Variabel Kurikulum Darussalam lebih dominan pengaruhnya dibandingkan dengan Kurikulum 2013 terhadap minat belajar santri di Pondok Pesantren Ma'arif Assunniyyah Tambarangan Kecamatan Tapin Selatan Kabupaten Tapin.

Jenis Penelitian yang digunakan dalam penelitian ini adalah penelitian lapangan (field research) dengan menggunakan dua jenis pendekatan (mix method), yakni penelitian yang menggunakan pendekatan kualitatif dan kuantitatif. Peneliti menggunakan mix method karena memerlukan kedua jenis pendekatan penelitian tersebut guna mengolah data yang dikumpulkan agar dapat menghasilkan kesimpulan yang komprehensif. Variabel dapat dimaknai sebagai atribut maupun objek, yang menurut Nisfihannoor (2009: 7) dibagi menjadi dua jenis, yakni variabel independen dan variabel dependen. Sedangkan menurut Arikunto (2010: 118) variabel merupakan hal-hal yang menjadi objek penelitian yang ditatap dalam kegiatan penelitian yang menunjukkan variasi baik secra kuantitatif maupun kualitatif. Dalam penelitian ini variabel yang dimaksud adalah:

1. Variabel Bebas (independent) atau Variabel (X), yakni antesenden, prediktor. Variabel yang merupakan rangsangan untuk mempengaruhi variabel lain. Variabel ini mungkin menyebabkan atau mempengaruhi atau memberikan efek pada outcome dan menjadi penyebba perubahan atau munculnya variabel dependent. Dalam penelitian ini varibel independennya adalah Kurikulum 2013 (X1) dan Kurikulum Darussalam (X2).

2. Variabel terikat (dependent) atau variabel (Y), yakni variabel yang berupa konsekuensi atau kriterium. Variabel ini merupakan variabel yang dipengaruhi atau yang menjadi akibat dari variabel indpendent. Variabel yang merupakan hasil dari perilaku yang di rangsang. Dalam penelitian ini variabel dependentnya adalah minat belajar santri (Y).

Populasi dalam penelitian ini adalah seluruh santri yang berstatus sebagai siswa di tingkat Madrasah Tsanawiyah. Adapun jumlah populasinya adalah 561 orang santri dan yang dapat dihimpun sebesar 553 santri, 40 orang guru yang menerapkan kurikulum 2013, dan 23 orang ustadz/ustadzah yang menerapkan kurikulum Darussalam. Adapun yang menjadi sampel dalam penelitian ini adalah seluruh populasi yang ada di dalam penelitian. Seluruh populasi diambil menjadi sampel penelitian karena peenliti menggunakan teknik pengambilan 
sampel jenuh, di mana seluruh populasi dijadikan sampel, yakni 561 responden yang berasal dari kalangan santri, 40 orang kalangan guru yang menerapkan kurikulum 2013, dan 23 orang ustadz/ustadzah yang menerapkan kurikulum Darussalam. Selain mudahnya akses bagi peneliti untuk mengambil data dengan survey, teknik ini juga digunakan dengan alasan untuk mengambil data yang paling akurat dan representatif dalam menggambarkan minat belajar santri di Pondok Pesantren Ma'arif Assunniyyah Tambarangan Kecamatan Tapin Selatan Kabupaten Tapin dengan menggunakan dua jenis kuikulum, yakni kurikulum 2013 dan kurikulum Darussalam.

Dalam penelitian ini teknik pengumpulan data yang digunakan oleh peneliti adalah angket/kuesioner, wawancara, observasi, dokumentasi dan focus group discussion. Peneliti memerlukan angket sebagai instrumen penelitian guna memperoleh data mengenai minat belajar santri dan impelementasi kurikulum. Selanjutnya instrumen angket ini akan diuji tingkat validitas dan reliabilitasnya. Selanjutnya dilakukan uji asumsi klasik adalah pengujian pada variabel penelitian dengan model regresi, apakah dalam variabel dan model regresinya terjadi kesalahan. Untuk mendapatkan model regresi yang baik harus terbebas dari penyimpangan data yang terdiri dari normalitas, multikolonieritas, dan heteroskedastisitas. Dalam penelitian ini terhadap data yang berbentuk kuanitatif, akan dilakukan analisis data merupakan kegiatan setelah data dari seluruh responden atau sumber data terkumpul. Kegiatan dalam analisis data adalah: mengelompokkan data berdasarkan variabel [Yakni Variabel Kurikulum 2013 (X1), Variabel kurikulum Darussalam (X2) dan variabel minat belajar santri (Y)] dan jenis responden, mentabulasi data berdasarkan variabel dan responden. Menyajikan data tiap variabel yang diteliti, melakukan penghitungan untuk menyawab rumusan masalah, dan melakukan perhitungan untuk menjawab rumusan masalah, dan melakukan perhitungan untuk menguji hipotesis yang telah diajukan (Sugiyono, 2015: 147). Adapun teknik analisis yang digunakan dalam penelitian adalah dengan mengunakan analisis statistik menggunakan aplikasi SPSS. Teknik analisis yang digunakan dalam penelitian ini adalah regresi linear sederhana dan berganda. Selanjutnya dilakukan uji hipotesis jika data menunjukkan adanya pengaruh, yang digunakan untuk mengetahui apakah hipotesis yang diajukan tersebut terbukti atau tidak, dengan menggunakan perhitungan uji statistik. Peneliti juga akan menggunakan koefisien determinasi. Analisis determinasi dalam regresi linear berganda digunakan untuk mengetahui presentase sumbangan pengaruh variabel independen terhadap variabel dependen. Di sini juga telah terlihat pengaruh yang dominan. Dari data ini juga digunakan untuk membandingkan nilai pengaruh setiap variabel tersebut, apakah Kurikulum 2013 yang lebih besar nilai pengaruhnya terhadap minat belajar santri ataukah Kurikulum Darussalam yang lebih besar nilai pengaruhnya.

\section{Hasil Penelitian dan Pembahasan}

Dari hasil penelitian yang dikumpulkan diketahui perbandingan pengaruh kedua kurikulum tersebut terhadap minat belajar santri Pondok Pesantren Ma'arif Assunniyyah Tambarangan. Diketahui bahwa terdapat $79,2 \%$ santri yang memberikan tanggapan positif terhadap proses pembelajaran dengan menggunakan kurikulum Darussalam, dan $89,7 \%$ santri yang memberikan pandangan positif terhadap proses pembelajaran dengan menggunakan kurikulum 2013. Santri lebih menyenangi kurikulum 2013, karena selama proses pembelajaran berlangsung dalam kurikulum 2013, kegiatan belajarnya lebih mampu menstimulus perasaan senang santri dalam proses belajar. Selain itu juga diketahui bahwa $92,6 \%$ santri menyukai proses pembelajaran dengan kurikulum 2013, sedangkan santri yang menyukai 
proses pembelajaran dengan kurikulum Darussalam hanya sebesar $82,1 \%$. Perbedaan tanggapan positif ini disebabkan beberapa faktor, salah satu di antaranya adalah kurikulum 2013 lebih melibatkan santri dalam kegiatan belajar. Santri lebih menyukai proses pembelajaran yang lebih sering terjadi interaksi antara guru dan santri dibandingkan dalam penerapan pembelajaran dengan kurikulum yang menekankan santri untuk hanya sekedar menyimak dengan kuantitas interaksi yang minim.

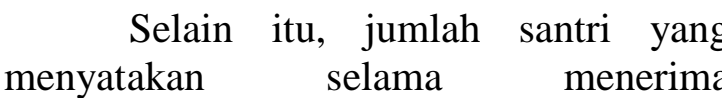
pembelajaran dengan kedua kurikulum juga berbeda. $4,5 \%$ santri menyatakan bahwa mereka tidak senang menerima pembelajaran dengan kurikulum Darussalam sedangkan pada kurikulum 2013 hanya terdapat 1,4\% santri yang menyatakan tidak senang menerima pembelajaran dengan kurikulum 2013. Sebaliknya terdapat $94 \%$ santri yang senang menerima pembelajaran dengan kurikulum 2013 sedangkan pada kurikulum Darussalam hanya terdapat $83,5 \%$. Santri lebih senang menerima pembelajaran dengan kurikulum 2013 karena memang pada dasarnya kurikulum 2013 berisi materi-materi yang lebih familiar bagi santri seperti muatan materi pada mata pelajaran bahasa Indonesia, matematika, pendidikan kewarganegaraan, dibandingkan dengan uatan materi pada kitab-kitab klasik yang dipelajari dalam kurikulum Darussalam, di mana santri merasa perlu belajar bahasa arab, tata bahasa arab, nahwu dan shoraf serta tafsir lebih banyak lagi. Ini menunjukkan bahwa mereka perlu belajar lebih banyak pada kurikulum Darussalam. Sayangnya, berdasarkan data yang diperoleh diketahui bahwa terdapat $4,5 \%$ santri yang tidak terus menerus mempelajari materi-materi pembelajaran pada kurikulum Darussalam. Jumlah persentase santri yang menyatakan bahwa mereka harus terus menerus mempelajari materi dalam kedua kurikulum tersebut cukup berbeda, $85 \%$ santri menyatakan bahwa mereka terus menerus mempelajari materi pada kurikulum 2013, sedangkan pada kurikulum Darussalam hanya terdapat $70 \%$ santri yang terus menerus mempelajari mataeri. Faktor tingkat kesulitan isi materi yang harus dikuasai menjadi alasan utama para santri dalam mempelajari materi secara kontinue, materi pada kurikulum Darussalam dianggap lebih sulit dibandingkan dengan materi pada kurikulum 2013. Proses pembelajaran pada kedua kurikulum ditanggapi berbeda oleh santri Pondok Pesantren Ma'arif Assunniyyah. Diketahui bahwa 79,2\% santri tidak merasa bosan belajar dengan kurikulum Darussalam sedangkan pada kurikulum 2013 jumlah santri yang merasa tidak bosan dalam belajar memiliki porsentase lebih besar yakni sebesar $89,5 \%$. 16,5\% santri yang menyatakan cukup bosan belajar dengan kurikulum Darussalam menyebutkan beberapa alasan di antaranya ustadz/ustadzah lebih banyak menggunakan metode ceramah selama proses pembelajaran dibandingkan dengan metode mengajar lainnya. Bahkan ada santri yang menyebutkan bahwa kegiatan diskusi hanya memakan waktu yang sangat sedikit dalam pembelajaran dengan kurikulum Darussalam, hal ini disebabkan karena kitab klasik yang sedang dipelajari lebih banyak dibacakan oleh ustadz/ustadzah. Deskripsi ini menunjukkan bahwa kurikulum 2013 lebih mempengaruhi minat belajar santri dibandingkan dengan kurikulum Darussalam.

Berdasarkan data yang telah dipaparkan sebelumnya, dapat dibandingkan pengaruh antara kurikulum 2013 dan kurikulum Darussalam terhadap minat belajar santri juga dapat dilihat porsentase keterlibatan aktif santri dalam proses pembelajaran dalam kedua kurikulum tersebut. Sebesar $87,7 \%$ santri terlibat aktif dalam kegiatan belajar pada kurikulum 2013, sedangkan pada kurikulum Darussalam hanya terdapat $80,1 \%$ santri yang terlibat aktif dalam proses pembelajaran. Santri Pondok Pesantren Ma'arif Assunniyyah yang menunjukkan sikap aktif belajar selama 
proses pembelajaran ditandai dengan adanya ketertarikan untuk membaca berbagai sumber bacaan yang dapat mendukung informasi untuk menambah pengetahuannya. Selain itu santri tersebut juga tidak merasa terbatas untuk memahami berbagai kitab atau sumber pengetahuan maupun materi. Mereka tidak memerlukan waktu khusus untuk belajar, namn jika ada materi yang belum mereka kuasai, para santri tersebut lebih menghabiskan waktu untuk mempelajari materi tersebut, meskipun di akhir pekan. Santri yang aktif dalam kegiatan belajar ini juga ditandai dengan selalu tampil dan memiliki keberanian untuk bertanya pada hal yang tidak dipahami, sering berfikir kritis dan analitis. Dalam proses pembelajaran lebih proaktif dan beraktifitas secara mandiri. Bahkan menghabiskan waktu untuk sharing pengetahuan dengan santri yang lain. Di sisi lain perbedaan juga nampak pada persiapan santri untuk belajar dalam kegiatan belajar di kedua kurikulum tersebut. Diketahui bahwa terdapat $92,6 \%$ santri yang menyiapkan pembelajaran pada kurikulum 2013, sedangkan porsentase santri yang menyiapkan pembelajaran pada kurikulum Darussalam hanya sebesar $78,4 \%$. Persiapan belajar dilakukan dalam dua hal, yakni persiapan fisik dan persiapan mental. Persiapan fisik yang dimaksud adalah santri mempersiapkan dirinya dengan membekali beberapa alat untuk membantunya belajar, seperti menyiapkan kamus, kitab, buku catatan, pensil, dan bahkan mengetahui dengan jelas jadwal dan materi yang akan dipelajari. Sedangkan mempersiapkan mental yang dimaksud berupa persiapan santri Pondok Pesantren Ma'arif Assunniyyah yang meliputi membuat fokus dan konsentrasi untuk mengikuti jalannya proses belajar.

Berdasarkan data yang dipaparkan sebelumnya juga dapat dibandingkan antara porsentase santri yang mengalami cukup kejenuhan dalam mengikuti proses pembelajaran di kedua kurikulum tersebut. Terdapat $21,3 \%$ santri yang cukup jenuh dalam kegiatan belajar pada Kurikulum Darussalam, sedangkan pada kurikulum
2013 hanya terdapat 10,5\% santri yang merasa cukup jenuh. Di satu sisi juga dapat dilihat perbandingan antara jumlah santri yang tidak merasa jenuh selama proses pembelajaran, yakni terdapat $86,4 \%$ santri pada kurikulum 2013, dan hanya 72,5\% santri pada kurikulum Darussalam yang menyatakan tidak pernah merasa jenuh untuk mengikuti kegiatan pembelajaran. Santri Pondok Pesantren Ma'arif Assunniyyah mengalami kejenuhan dalam belajar disebabkan oleh beberapa faktor, di antaranya kegiatan pembelajar yang bersifat rutin dan monoton, metode strategi yang dipergunakan dalam proses pembelajaran kurang bervariasi, materi yang dianggap sulit untuk dikuasai, santri harus menambah porsi waktu untuk dapat menguasai satu materi, santri merasa kurang percaya diri untuk menguasai materi, dan ruang belajar yang tidak pernah berpindah-pindah atau bersifat tetap. Faktor inilah yang menyebabkan santri mengalami kejenuhan dalam proses pembelajaran baik pada kurikulum 2013 maupun kurikulum Darussalam.

Pengaruh kurikulum 2013 dan kurikulum Darussalam terhadap minat belajar santri juga dapat dilihat dari keinginan santri untuk mencari tantangan pada isi materi belajar yang dipergunakan dalam kurikulum tersebut. Terdapat $74 \%$ santri yang mencari tantangan pada isi materi dalam pembelajaran kurikulum 2013, sedangkan pada kurikulum Darussalam hanya terdapat $68,4 \%$. Ini menunjukkan bahwa isi materi dan penyampaian materi juga menjadi pemicu minat santri untuk belajar. Minimnya porsentase pada penerapan kurikulum Darussalam diketahui bahwa sumber belajar yang dipergunakan hanya kitab tertentu sehingga santri tidak terlalu tertantang untuk mendalami materi tanpa bimbingan guru atau ustadz. Dalam dunia pesantren sangat ditekankan bahwa ketika belajar agama haruslah berpedoman pada kitab yang diajarkan secara langsung oleh ustadz atau tuan guru, agar ilmu agama yang diperoleh dapat lebih beberkah. Di Pondok Pesantren Ma'arif Assunniyyah 
diguanakan beberapa kitab yang diajarkan secara langsung oleh seorang ustadz kepada santri.

Ketika melihat perbandingan porsentase santri yang tidak menunda tugas atau pekerjaan rumah pada kedua kurikulum tersebut, juga dapat diketahui bahwa sebesar $51 \%$ santri tidak menunda mengerjakan tugas yang diberikan oleh guru pada proses pembelajaran yang menggunakan kurikulum 2013, sedangkan pada kurikulum Darussalam terdapat 49,6\% yang tidak menunda mengerjakan tugas. Kegiatan mengerjakan tugas dengan segera menunjukkan adanya minat santri dalam belajar. Pada kurikulum Darussalam tugas yang diberikan biasanya berupa mengerjakan soal ataupun latihan, sedangkan pada Kurikulum Darussalam, tugas yang diberikan biasanya membaca isi kitab klasik yang digunakan secara mandiri. Untuk melihat perbandingan pengaruh kurikulum 2013 dan kurikulum Darussalam terhadap minat belajar santri juga dapat dilihat dari konsentrasi, baik konsentrasi dalam belajar, konsentrasi dalam memperhatikan penjelasan, maupun konsentrasi santri dalam menyelesaikan tugas. Terdapat $88,4 \%$ santri yang konsentrasi dalam belajar pada kurikulum 2013, sedangkan pada kurikulum Darussalam hanya terdapat $74 \%$ santri yang konsentrasi dalam belajar. Selanjutnya, jika dilihat dari konsentrasi santri dalam memperhatikan penjelasan guru, juga diketahui bahwa adanya perbedaan yangcukup signifikan, di mana $92,5 \%$ santri memperhatikan penjelasan dalam kurikulum 2013 dan pada kurikulum Darussalam hanya terdapat $76,9 \%$ santri yang konsentrasi dalam memperhatikan penjelasan guru selama proses pembelajaran berlangsung. Dalam penyelesaian tugas pun juga demikian. Jumlah porsentase santri yang konsentrasi dalam menyelesaikan tugas pada kurikulum 2013 lebih besar dibandingkan dnegan jumlah porsentase santri yang konsentrasi dalam menyelesaikan tugas pada kurikulum Darussalam, yakni masing-masing sebesar $89,7 \%$ dan $78,5 \%$. Selain itu perbandingan pengaruh kedua kurikulum terhadap minat belajar snatri juga dapat dilihat dari aktivitas santri dalam mencatat materi. Berdasarkan data yang ada diketahui bahwa terdapat $82,1 \%$ santri yang mencatat materi pada proses pembelajaran dalam kurikulum 2013 sedangkan pada kurikulum Darussalam hanya terdapat $79 \%$ santri yang mencatat materi. Materi yang dicatat pada kurikulum Darussalam biasanya berupa penjelasan ustadz mengenai isi kitab dan terjemahan dari isi kitab yang dipergunakan dalam proses pembelajaran.

Pengaruh kurikulum terhadap minat belajar santri juga dapat diketahui dari jumlah porsentase santri yang memiliki kesadaran akan adanya manfaat dari belajar dan kemampuan mereka untuk menemukan manfaat dari belajar. Terdapat $97,1 \%$ santri yang sadar akan adanya manfaat dalam mempelajari materi pada kurikulum 2013 dan pada kurikulum Darussalam terdapat $89,3 \%$ santri yang menyadarinya. Di sisi lain terdapat $95,7 \%$ santri yang menemukan manfaat dari belajar pada kurikulum 2013 dan pada kurikulum terdapat $89,3 \%$ santri. Adanya manfaat dalam belajar dapat meningkatkan minat santri untuk mempelajari materi tersebut. Pada proses pembelajaran kurikulum 2013 biasanya guru selalu menmyampaikan tujuan pembelajaran,sedangkan pada kurikulum Darussalam ustadz hanya menyampaikan bahwa sanri akan mempelajari materi selanjutnya atau menyambung pembahasan pada kitab yang telah dipelajari tersebut, beberapa ustadz menyampaikan tujuan pembelajaran, beberapa di antaranya tidak. Dari beberapa indiaktor ini dapat dideskripsikan bagaimana perbandingan pengaruh kurikulum 2013 dan kurikulum Darussalam terhadap minat belajar santri.

\section{Analisis Regresi dan Uji Hipotesis}

Pengujian hipotesis ini berisi tentang variabel-variabel penelitian yang akan di uji hipotesisnya, ada tiga hipotesis yang diuji yaitu: (1) Pengaruh Kurikulum 2013 (X1) dan Kurikulum Darussalam (X2) secara simultan terhadap minat belajar santri (Y) di Pondok Pesantren Ma'arif 
Assunniyyah Tambarangan Kecamatan Tapin Selatan Kabupaten Tapin. (2) Pengaruh Kurikulum 2013 (X1) dan Kurikulum Darussalam (X2) secara parsial terhadap minat belajar santri (Y) di Pondok Pesantren Ma'arif Assunniyyah Tambarangan Kecamatan Tapin Selatan Kabupaten Tapin, dan (3) Variabel Kurikulum Darussalam (X2) lebih dominan pengaruhnya dibandingkan dengan Kurikulum 2013 (X1) terhadap minat belajar santri (Y) di Pondok Pesantren Ma'arif Assunniyyah Tambarangan Kecamatan Tapin Selatan Kabupaten Tapin. Yang akan diapaparkan sebagai berikut:

Uji pengaruh secara parsial Kurikulum 2013 terhadap minat belajar santri di Pondok Pesantren Ma'arif Assunniyyah Tambarangan

Hipotesis yang akan diuji pada bagian ini adalah: kurikulum 2013 (X1) berpengaruh terhadap minat belajar santri di Pondok pesantren Maarif Assunniyyah Tambarangan (Y). Hipotesis tersebut adalah hipotesis alternatif, dalam rangka keperluan uji hipotesis yang nihil, sehingga berbunyi "Kurikulum Darussalam dan Kurikulum 2013 berpengaruh secara parsial terhadap minat belajar santri di Pondok Pesantren Ma'arif Assunniyyah Tambarangan Kecamatan Tapin Selatan Kabupaten Tapin"

Uji hipotesis yang parsial pertama yakni menganalisis pengaruh Kurikulum 2013 (X1) terhadap minat belajar santri (Y), yang dilakukan dengan regresi linear sederhana menggunakan SPSS, yang hasilnya Nilai $\mathrm{R}$ sebesar 0,179 menunjukkan hasil korelasi antara Kurikulum 2013 dengan minat belajar santri Pondok Pesantren Maarif Assunniyyah Tambarangan. Sedangkan nilai $\mathrm{R}$ Square ( atau $\mathrm{R}^{2}$ ) sebesar 0.032 menunjukkan bahwa 3,2\% perubahan pada minat belajar santri dapat dijelaskan oleh Kurikulum 2013. Sedangkan tingkat signifikansi pengaruh dari variabel bebas terhadap variabel terikat dapat dilambangkan:
Nilai Sig $<0,05$ maka pengaruhnya signifikan

Nilai Sig > 0,05 maka pengaruhnya tidak signifikan

Dari hasil analisis diketahui bahwa Kurikulum 2013 memiliki nilai Sig $=0,270$ (Lebih besar dari 0,05) yang artinya "Kurikulum 2013" memiliki pengaruh yang tidak signifikan terhadap "minat belajar santri", artinya meskipun ada pengaruh namun nilainya tidak besar. Kurikulum 2013 memiliki nilai Unstandardized Coeficients sebesar $-0,630$ yang menunjukkan besaran pengaruh dari Kurikulum 2013 terhadap minat belajar santri Pondok Pesantren Maarif Assunniyyah Tambarangan sebesar $-0,630$. Kurikulum 2013 memiliki nilai Unstandardized Coeficients yang negatif, yang artinya pengaruhnya bersifat berlawanan arah. Di mana seharusnya semakin baik implementasi kurikulum 2013, semakin tinggi pula minat belajar santri, atau sebaliknya semakin buruk implementasi kurikulum 2013, semakin rendah minat belajar santri. Namun dalam kasus ini pernyataan yang muncul tidak searah, karena adanya nilai yang negatif, itu artinya kedua variabel memiliki pengaruh yang bersifat bertolak belakang. Maksudnya adalah jika variabel bebas (X1) naik, maka variabel terikat (Y) akan turun, dan sebaliknya jika variabel bebas turun (X1), maka variabel terikatnya akan naik. Artinya implementasi kurikulum 2013 secara parsial memiliki pengaruh yang tidak signifikan terhadap minat belajar santri Pondok Pesantren Maarif Assunniyyah Tambarangan. Banyak faktor lainnya yang menyebabkan tingginya minat belajar santri.

Uji pengaruh secara parsial Kurikulum Darussalam terhadap minat belajar santri di Pondok Pesantren Ma'arif Assunniyyah Tambarangan

Hipotesis yang juga akan diuji pada bagian ini adalah: kurikulum Darussalam (X2) berpengaruh terhadap minat belajar santri di Pondok pesantren Maarif Assunniyyah Tambarangan (Y). Hipotesis 
tersebut adalah hipotesis alternatif, dalam rangka keperluan uji hipotesis yang nihil, sehingga berbunyi "Kurikulum Darussalam dan Kurikulum 2013 berpengaruh secara parsial terhadap minat belajar santri di Pondok Pesantren Ma'arif Assunniyyah Tambarangan Kecamatan Tapin Selatan Kabupaten Tapin"

Uji hipotesis yang parsial pertama yakni menganalisis pengaruh Kurikulum 2013 (X1) terhadap minat belajar santri (Y), yang dilakukan dengan regresi linear sederhana menggunakan SPSS, yang hasilnya yang menunujukkan Nilai $R$ sebesar 0,062 menunjukkan hasil korelasi antara Kurikulum Darussalam dengan minat belajar santri Pondok Pesantren Maarif Assunniyyah Tambarangan. Sedangkan nilai R Square ( atau $\mathrm{R}^{2}$ ) sebesar 0.004 menunjukkan bahwa $0,4 \%$ perubahan pada minat belajar santri dapat dijelaskan oleh Kurikulum Darussalam. Tingkat signifikansi pengaruh dari variabel bebas terhadap variabel terikat dapat dinyatakan:

Nilai Sig $<0,05$ maka pengaruhnya signifikan

Nilai Sig > 0,05 maka pengaruhnya tidak signifikan

Dari hasil statistik diketahui bahwa Kurikulum Darussalam memiliki nilai Sig = 0,779 (Lebih besar dari 0,05) yang artinya Kurikulum Darussalam memiliki pengaruh yang tidak signifikan terhadap "minat belajar santri", artinya ada pengaruh namun nilainya tidak terlalu besar. Kurikulum Darussalam memiliki nilai Unstandardized Coeficients sebesar 0,129 yang menunjukkan besaran pengaruh dari Kurikulum Darussalam terhadap minat belajar santri Pondok Pesantren Maarif Assunniyyah Tambarangan sebesar 0,129. Kurikulum Darussalam memiliki nilai Unstandardized Coeficients yang positif, yang artinya pengaruhnya bersifat searah. Di mana semakin baik implementasi kurikulum Darussalam, semakin tinggi pula minat belajar santri, atau sebaliknya semakin buruk implementasi kurikulum Darussalam, semakin rendah minat belajar santri. Namun dalam kasus ini, pernyataan yang muncul adalah searah, karena adanya nilai yang positif, itu artinya kedua variabel memiliki pengaruh yang bersifat searah. Maksudnya adalah jika variabel bebas (X2) naik, maka variabel terikat (Y) juga akan meningkat, dan sebaliknya jika variabel bebas turun (X2), maka variabel terikatnya juga akan ikut turun. Artinya baik buruknya implementasi kurikulum Darussalam secara parsial meskipun memiliki nilai koefisien positif namun memiliki pengaruh yang tidak signifikan terhadap minat belajar santri Pondok Pesantren Maarif Assunniyyah Tambarangan. Sekali lagi, banyak faktor lainnya yang menyebabkan tingginya minat belajar santri, tidak hanya kurikulum.

\section{Uji pengaruh secara simultan} Kurikulum Darussalam dan Kurikulum 2013 terhadap minat belajar santri di Pondok Pesantren Ma'arif Assunniyyah Tambarangan

Hipotesis yang juga akan diuji pada bagian ini adalah pengaruh kurikulum 2013 (X1) dan Kurikulum Darussalam (X2) secara simultan terhadap minat belajar santri di Pondok pesantren Maarif Assunniyyah Tambarangan (Y). Hipotesis tersebut adalah hipotesis alternatif, dalam rangka keperluan uji hipotesis yang nihil, sehingga berbunyi "Kurikulum Darussalam dan Kurikulum 2013 berpengaruh secara simultan terhadap minat belajar santri di Pondok Pesantren Ma'arif Assunniyyah Tambarangan Kecamatan Tapin Selatan Kabupaten Tapin"

Uji hipotesis simultan ini dilakukan dengan regresi linear berganda menggunakan SPSS, yang hasilnya menunjukkan bahwa Nilai $\mathrm{R}$ Square = 0,019 atau $0,19 \%$ yang artinya perubahan minat belajar santri dapat dijelaskan oleh Kurikulum 2013 dan Kurikulum Darussalam sebesar 0,19\%, sedangkan sisanya $99,81 \%$ adalah faktor lainnya yang menjelaskan perubahan minat belajar santri Pondok Pesantren Maarif Assunniyyah Tambarangan. Banyak faktor yang mempengaruhi minat belajar santri. 


\section{Uji Signifikansi Simultan (Uji F)}

Tabel 1 Regresi

\begin{tabular}{|l|r|r|r|r|r|}
\hline Model & $\begin{array}{r}\text { Sum of } \\
\text { Squares }\end{array}$ & df & $\begin{array}{c}\text { Mean } \\
\text { Square }\end{array}$ & F & Sig. \\
\hline $1 \quad$ Regression & 316.385 & 2 & 158.192 & .189 &. $.830^{a}$ \\
Residual & 16775.267 & 20 & 838.763 & & \\
Total & 17091.652 & 22 & & & \\
\hline
\end{tabular}

a. Predictors: (Constant),

$\mathrm{X} 2, \mathrm{X} 1$

b. Dependent Variable: Y

Data regression pada tabel memiliki nilai Sig. $=0,830$ (lebih besar dari 0,05 ) yang artinya kedua variabel bebas pada penelitian ini secara simultan tidak mempengaruhi variabel terikat. Artinya variabel kurikulum 2013 (X1) dan Kurikulum Darussalam (X2) secara simultan tidak mempengaruhi secara signifikan terhadap variabel minat belajar santri (Y), atau pengaruhnya tidak signifikan. Berdasarkan perbandingan nilai F Hitung dan F Tabel juga dapat dilihat hasil uji untuk pengaruh kurikulum 2013 (X1) dan kurikulum Darussalam (X2) terhadap minat belajar santri (Y), dimana: Nilai $F$ hitung $>$ F tabel maka pengaruhnya signifikan. Artinya kurikulum 2013 (X1) dan kurikulum Darussalam (X2) secara simultan berpengaruh terhadap minat belajar santri (Y). Sebaliknya, Nilai F hitung $<\mathrm{F}$ tabel maka pengaruhnya tidak signifikan. Artinya kurikulum 2013 (X1) dan kurikulum Darussalam (X2) secara simultan tidak berpengaruh terhadap minat belajar santri (Y).

Berdasarkan hal ini jika dilihat dari tabel berikut:

Tabel 2 Perbandingan F Hitung dan F Tabel

\begin{tabular}{|l|r|r|r|}
\hline \multicolumn{1}{|c|}{ Variabel } & \multicolumn{1}{c|}{$\begin{array}{c}\text { F } \\
\text { Hitung }\end{array}$} & $\begin{array}{c}\text { F } \\
\text { Tabel }\end{array}$ & Kesimpulan \\
\hline $\begin{array}{l}\text { Kurikulum 2013 } \\
\text { X1) }\end{array}$ & 0,18 & 3,42 & $\begin{array}{r}\text { Pengaruh tidak } \\
\text { signifikan, } \\
\text { hipotesis } \\
\text { Kurikulum } \\
\text { Darussalam (X2) }\end{array}$ \\
\hline
\end{tabular}

Tabel 3 Signifikansi Variabel Kurikulum 2013 dan Kurikulum Darussalam

\begin{tabular}{|c|r|r|r|r|}
\hline \multirow{2}{*}{ Model } & \multicolumn{2}{|c|}{$\begin{array}{c}\text { Unstandardized } \\
\text { Coefficients }\end{array}$} & $\begin{array}{c}\text { Standardized } \\
\text { Coefficients }\end{array}$ & \multirow{2}{*}{ Sig. } \\
\cline { 2 - 4 } & \multicolumn{1}{|c|}{ B } & \multicolumn{1}{c|}{$\begin{array}{c}\text { Std. } \\
\text { Error }\end{array}$} & \multicolumn{1}{c|}{ Beta } & \\
\hline 1 (Constant) & 246.144 & 93.775 & & .016 \\
X1 & -.464 & .849 & -.122 & .590 \\
X2 & .164 & .466 & .079 & .729 \\
\hline
\end{tabular}

a. Dependent

Variable: Y

Karena data telah menunjukkan bahwa hipotesis ditolak atau variabel Kurikulum 2013 (X1) dan Kurikulum Darussalam (X2) tidak berpengaruh secara signifikan terhadap minat belajar santri (Y), maka peneliti boleh saja sebenarnya tidak melanjutkan ke uji hipotesis yang menggunakan Mann Whitney Test. Sedangkan melalui tabel Coeficients dapat ditarik beberapa kesimpulan sebagai berikut:

Variabel Kurikulum 2013 memiliki nilai Sig. $=0,590$ (lebih besar dari 0,05 ) yang artinya Kurikulum 2013 memiliki pengaruh yang tidak signifikan.

Variabel Kurikulum Darussalam memiliki nilai Sig. $=0,729$ (lebih besar dari 0,05) yang artinya Kurikulum Darussalam juga tidak mempengaruhi minat belajar santri secara signifikan Pondok Pesantren Maarif Assunniyyah Tambarangan. Berdasarkan Unstandardized Coeficients Beta, Kurikulum Darussalam memiliki skor yang lebih tinggi $(0,079)$ daripada Kurikulum 2013 (-0,122), yang artinya Kurikulum Darussalam memiliki pengaruh yang dominan terhadap minat belajar santri dibandingkan variabel lain yang diteliti (karena Kurikulum 2013 tidak memiliki pengaruh yang signifikan terhadap minat belajar santri, maka secara otomatis Kurikulum Darussalam merupakan satusatunya variabel bebas yang tersisa, sehingga menjadi variabel yang berpenagruh dominan (meskipun tidak signifikan) terhadap minat belajar santri (hal ini dapat diputuskan tanpa harus membandingkan nilai "Standardized Coeficients Beta” nya). 
Pengaruh Dominan terhadap minat belajar santri di Pondok Pesantren Ma'arif Assunniyyah Tambarangan

Uji indikator dominan dipergunakan untuk melihat indikator memiliki pengaruh tertinggi terhadap minat belajar santri, sehingga dapat digunakan sebagai bahan pertimbangan untuk kebijakan pengembangan kurikulum selanjutnya. Untuk menguji variabel mana yang dominan pengaruhnya, terlebih dahulu peneliti perlu mengetahui kontribusi masing-masing variabel, dalam hal ini variabel Kurikulum 2013dan Kurikulum Darussalam, dilihat dari coeficients determinasi regresi sederhana terhadap variabel terikat (minat belajar santri pondok pesantren Maarif assunniyyah Tambarangan) atau dapat juga diketahui dari kuadrat korelasi sederhana variabel bebas dan terikat. Sebagaimana berikut ini: Tabel 4 Hasil Data Dominan

\begin{tabular}{|l|l|l|l|}
\hline Variabel & $\mathrm{R}$ & $\mathrm{R} 2$ & Kontribusi \\
\hline Kurikulum 2013 (X1) & 0,179 & 0,032 & $3,2 \%$ \\
Kurikulum & 0,062 & 0,004 & $0,4 \%$ \\
Darussalam (X2) & & & \\
\hline
\end{tabular}

Dari tabel tersebut diketahui bahwa indikator yang lebih dominan pengaruhnya adalah Kurikulum 2013 (X1), sedangkan untuk variabel kurikulum Darussalam hanya memiliki kontribusi $0,4 \%$. Keduanya tidak memberikan pengaruh yang signifikan terhadap minat belajar santri Pondok Pesantren Ma'arif Assunniyyah Tambarangan.

\section{Perbandingan Pengaruh Varibael Kurikulum 2013 (X1) dan Kurikulum Darussalam (X2) terhadap variabel Minat Belajar Santi (Y)}

Berdasarkan hasil perbandingan $\mathrm{R}$ dan R2 dapat diketahui bahwa Kurikulum 2013 (X1) memiliki pengaruh yang lebih dominan terhadap minat belajar santri Pondok Pesantren Ma'arif Assunniyyah Tambarangan, yakni sebesar 3,2\%, dibandingkan dengan Kurikulum Darussalam (X2) yang hanya memberikan kontribusi sebesar 0,4\%. Dari data ini kita juga dapat melihat bahwa kontribusi ini juga dapat menggambarkan perbandingan secara deskriptif antara kurikulum 2013 dan kurikulum Darussalam yang diterapkan di Pondok Pesantren Ma'arif Assunniyyah Tambarangan.

\section{Kesimpulan}

Berdasarkan uji regresi linear sederhana diketahui bahwa Kurikulum 2013 memiliki nilai Sig = 0,270 (Lebih besar dari 0,05 ) yang artinya secara parsial "Kurikulum 2013" memiliki pengaruh yang tidak signifikan terhadap "minat belajar santri", artinya meskipun ada pengaruh namun nilainya tidak besar. Kurikulum 2013 memiliki nilai Unstandardized Coeficients sebesar -0,630 yang menunjukkan besaran pengaruh dari Kurikulum 2013 terhadap minat belajar santri Pondok Pesantren Maarif Assunniyyah Tambarangan sebesar -0,630. Berdasarkan hasil uji regresi linear sederhana juga diketahui bahwa Kurikulum Darussalam memiliki nilai $\mathrm{Sig}=0,779$ (Lebih besar dari 0,05) yang artinya Kurikulum Darussalam secara parsial memiliki pengaruh yang tidak signifikan terhadap "minat belajar santri", artinya ada pengaruh namun nilainya tidak terlalu besar. Kurikulum Darussalam memiliki nilai Unstandardized Coeficients sebesar 0,129 yang menunjukkan besaran pengaruh dari Kurikulum Darussalam terhadap minat belajar santri Pondok Pesantren Maarif Assunniyyah Tambarangan sebesar 0,129. Berdasarkan hasil uji regresi linear beragnda diketahui bahwa data regresi pada ANOVA memiliki nilai Sig. $=0,830$ (lebih besar dari 0,05 ) yang artinya kedua variabel bebas pada penelitian ini secara simultan tidak mempengaruhi variabel terikat. Artinya variabel kurikulum 2013 (X1) dan Kurikulum Darussalam (X2) secara simultan tidak mempengaruhi secara signifikan terhadap variabel minat belajar santri (Y), atau pengaruhnya tidak signifikan. Berdasarkan hasil uji melihat nilai $\mathrm{R}$ maka diketahui bahwa terdapat Nilai $\mathrm{R}$ yang menunjukkan hasil korelasi antara Kurikulum 2013 dengan minat belajar 
santri Pondok Pesantren Maarif Assunniyyah Tambarangan sebesar 0,179. Sedangkan nilai R Square ( atau $\mathrm{R}^{2}$ ) sebesar 0.032 menunjukkan bahwa 3,2\%. Sedangkan Nilai R sebesar 0,062 untuk hasil korelasi antara Kurikulum Darussalam dengan minat belajar santri Pondok Pesantren Maarif Assunniyyah Tambarangan dengan nilai R Square ( atau $\mathrm{R}^{2}$ ) sebesar 0.004 menunjukkan bahwa 0 , 4\%. Jadi kontribusi yang lebih besar diberikan oleh Kurikulum 2013, meskipun terbilang kecil.

Berdasarkan data kualitatif juga dapat disimpulkan bahwa pembelajaran dengan kurikulum 2013 lebih besar pengaruhnya dibandingkan dengan kurikulum Darussalam. Hal ini dapat dilihat dari munculnya perasaan santri dalam mengikuti kegiatan pembelajaran dengan menggunakan kedua kurikulum tersebut, Perbedaan pengaruh juga terlihat dalam keterlibatan santri pada kegiatan pembelajaran, ketertarikan pada kegiatan belajar, perhatian dalam belajar, dan manfaat dalam belajar. Di mana dalam berbagai aspek ini, persentase penerapan kurikulum 2013 lebih besar pengaruhnya dibandingkan dengan kurikulum Darussalam.

Kurikulum meskipun nilainya kecil dalam memberikan kontribusi terhadap peningkatan minat belajar peserta didik, namun ia juga menjadi patokan utama dalam membuat tujuan pencapaian lembaga pendidikan. Oleh karenanya bagi lembaga pendidikan, diharapkan penyusunan kurikulum dikembangkan dnegan mengikuti alur pengembangan kurikulum sehingga output yang diharapkan juga tercapai. Minat belajar santri dapat ditingkatkan dengan melihat berbagai faktor lainnya, seperti media, fasilitas belajar, dan dukungan. Oleh karenanya kurikulum yang memuat segala aspek proses pendidikan dari hal terkecil hingga program yang besar perlu betul betul lebih bijaksana. Untuk peneliti selanjutnya diharapkan dapat merumuskan pengembangan kurikulum yang lebih baik untuk pondok pesantren, khususnya pondok pesantren salafi yang menjaga kultur tradisional.

\section{Daftar Pustaka}

A. S. Rizal. Transformasi corak edukasi dalam sistem pendidikan pesantren, dari pola tradisi ke pola modern. Jurnal pendidikan agama islam-ta'lim, 9(2), h. 95-112. 2011.

A, Sobandi dan Nurhasanah, S. Minat belajar sebagai determinan hasil belajar siswa. Jurnal pendidikan manajemen perkantoran, 1(1), h. 128-135, 2016.

A, Fadhilah. Struktur dan Pola kepemimpinan kyai dalam pesantren di Jawa. Hunafa: Jurnal Studia Islamika, 8(1), 101-120, 2011.

Aly, Abdullah. Pendidikan Islam Multikultural di Pesantren. Yogyakarta: Pustaka Pelajar, 2011.

Aarifin, Anwar. Memahami Paradigma Baru Pendidikan dalam Undangundang Sikdiknas. Jakarta: Ciputat Press, 2003.

Arifin, Zainal. Konsep dan Model pengembangan Kurikulum.

Bandungn: RemajaRosdakarya, 2012.

Asnawawi dan Maskhuri, Metodologi Riset Pemasaran, Malang: UIN Maliki Press, 2011

Ahmad, Syarwan. Problematika kurikulum 2013 dan kepemimpinan instruksional kepala sekolah. Jurnal Pencerahan, 8(2), 2014.

Abbas, Tashakkori, and John W. Creswell. The new era of mixed methods. h.37, 2007.

Arikunto, Suharsimi. Prosedur Penelitian Suatu Pendekatan Praktik. Jakarta: Rineka Cipta, 2010.

Arikunto, Suharsimi. Prosedur Penelitian, Jakarta, Rineka Cipta, 2002.

Arcana, N., Pengantar Statistik II untuk Ekonomi Bagian Inferensial, Surabaya: Fakultas Ekonomi Universitas Katolik Widya Mandala Surabaya, 2009. 
Aritonang, K. T. Minat dan motivasi dalam meningkatkan hasil belajar siswa. Jurnal pendidikan penabur, 7(10), 11-21, 2008.

Badan Pengembangan Sumber Daya Manusia Pendidikan dan Kebudayaan dan Penjaminan Mutu Pendidikan Kementerian Pendidikan dan Kebudayaan (2013). Materi Pelatihan Guru Implementasi Kurikulum 2013, Jakarta, kementerian Pendidikan dan Kebudayaan.

Best, John W. \& James V. Kahn. Research in Education Eight Editions. USA: Allyn and Bacon, 1998.

B.S. Bloom, Taxonomy of educational objectives: The classifi cation of educational goals. Handbook I: Cognitive domain. New York: David MacKay, 1956.

Beauchamp, G. A. Curriculum theory. Wilmette. Illinois: Kagg Publishing Company, 1968.

Daulay, Haidar Putra. Sejarah Pertumbuhan dan Pembaruan Pendidikan Islam di Indonesia. Jakarta: Kencana Prenada media Grup, 2007.

Daulay, Haidar Putra. Pemberdayaan Pendidikan Islam di Indoensia. Jakarta: Rineka Cipta, 2009.

Daulay, Haidar Putra. Pendidikan Islam dalam Sistem Pendidikan Nasional di indonsia,. Jakarta: Fajar Interpratama Offset, 2004.

Doll, R. C. Curriculum improvement: Decision making and process. Boston: Allyn and Bacon, 1970.

Departemen Agama, Majelis Pertimbangan dan Pemberdayaan Pendidikan Agama dan Keagamaan MP3A, Panduan Pembelajaran. Jakarta: BMPM, 2005.

Djamarah, Syaiful Bahri Psikologi Belajar. Jakarta: Rineka Cipta, 2008.

Depdikbud, Pembinaan Minat Baca, Materi Sajian, Jakarta: Dirjen Dikdasmen Depdikbud RI, 1997.

Irianto, Agus Statistik Konsep Dasar, Aplikasi, dan Pengembangannya.
Jakarta: Prenada Media Group, 2014.

Fadhilah, A. Struktur dan Pola kepemimpinan kyai dalam pesantren di Jawa. Hunafa: Jurnal Studia Islamika, 8(1), 101-120, 2011.

F, Olivia. Teknik Ujian Efektif. Jakarta: PT. Elex Media Komputindo, 2011.

Firdaus, Muhammad, Ekonometrika Suatu Pendekatan Aplikatif, Jakarta: Bumi Aksara, 2004.

Galen, Saylor John and William Marvin Alexander. Planning curriculum for schools. Holt, Rinehart and Winston, 1974.

Geertz, C., Mahasin, A., \& Rasuanto, B. Abangan, santri, priyayi: dalam masyarakat Jawa (No. 4). Pustaka Jaya, 1983.

Ghozali, Imam. Aplikasi Analisis Multivariate dengan Program IBM SPSS 20, Semarang: Universitas Diponegoro, 2012

Hamalik, Oemar Manajemen Pengembangan Kurikulum. Cet. IV. Bandung: Remaja Rosdakarya, 2010.

Hasan, Iqbal. Analisis Data Penelitian dengan Statistik. Jakarta: Bumi Aksara, 2010.

Hurlock, Elizabeth B. Perkembangan Anak. Jakarta: PT. Erlangga, 1995.

Hernawan, Asep Herry dkk, Pengembangan Kurikulum dan Pembelajaran. Jakarta: Penerbit UT, 2002.

Hidayat, Sholeh Pengembangan Kurikulum Baru. Bandung: Remaja Rosdakarya, 2013.

I. M., Putrayasa, Syahruddin, S. P., \& Margunayasa, I. G. Pengaruh model pembelajaran discovery learning dan minat belajar terhadap hasil belajar IPA siswa. MIMBAR PGSD Undiksha, 2(1), 2014.

I Gunawan, dan A. Palupi, $R$ Taksonomi Bloom-revisi ranah kognitif: kerangka landasan untuk pembelajaran, pengajaran, dan 
penilaian. Premiere educandum: jurnal pendidikan dasar dan pembelajaran, 2(02), 2016.

K. T, Aritonang. Minat dan motivasi dalam meningkatkan hasil belajar siswa. Jurnal pendidikan penabur, 7(10), 11-21, 2008.

K. Sumardi. Potret Pendidikan Karakter di Pondok Pesantren Salafiah. Jurnal Pendidikan Karakter, (3), 2012.

Katuuk, D. A. Manajemen implementasi kurikulum: strategi penguatanimplementasi kurikulum 2013. Cakrawala Pendidikan, (1), 2014.

Keputusan Dirjen Pendis No 481 Tahun 2015 Tentang Penunjukan Madrasah Lanjut Kurikulum 2013.

Keputusan Dirjen Pendis No 5114 tahun 2015 tentang Penetapan Madrasah Pelaksana Kurikulum 2013 Tahun Pelajaran 2015/2016.

Keputusan Menteri Agama Nomor 165 Tahun 2015 tentang Pedoman Kurikulum Madrasah 2013 Mapel PAI dan Bahasa Arab.

Lexy, Moleong J. Penelitian Kualutatif. Bandung: PT Remaja Rosdakarya, 2008.

Mahasin, A., Geertz, C., \& Rasuanto, B. Abangan, santri, priyayi: dalam masyarakat Jawa (No. 4). Pustaka Jaya, 1983.

Muhammad, Zaini. Pengembangan Kurikulum Konsep Implementasi Evaluasi dan Inovasi. Yogyakarta: teras, 2009.

M, Dalyono. Psikologi Belajar. Jakarta: Rineka Cipta, 2005.

Milles dan Huberman. Analisis Data Kualitatif. Jakarta: Universitas Indonesia Press, 1992.

Mulyasa, E. Kurikulum berbasis Kompetensi: Konsep, karakteristik, dan Implementasi. Bandung: Remaja Rosdakarya, 2003.

Nana Syaodih Sukmadinata. Pengembangan Kurikulum Teori dan Praktek. Bandung: Remaja Rosdakarya, 2005.
Nuh, M. Kurikulum 2013. Sumber: http://www. kemdiknas. go. id., 2013.

Nasution, S. Kurikulum dan Pengajaran. Jakarta: Bumi Aksara, 2008.

Nurhasanah, S., \& Sobandi, A. Minat belajar sebagai determinan hasil belajar siswa. Jurnal pendidikan manajemen perkantoran, 1(1), 135142, 2016.

Noor, H. H., \& Noor, H. H. Dinamika Kurikulum Pondok Pesantren di Kalimantan Selatan (Studi Pada Pondok Pesantren Darussalam Martapura, Ibnul Amin Pamangkih, Al-Falah Banjarbaru dan Darul Ilmi Banjarbaru), 2017.

Olivia, F. Teknik Ujian Efektif. Jakarta: PT. Elex Media Komputindo, 2011.

Putrayasa, I. M., Syahruddin, S. P., \& Margunayasa, I. G. Pengaruh Model Pembelajaran Discovery Learning Dan Minat Belajar Terhadap Hasil Belajar IPA Siswa. MIMBAR PGSD Undiksha, 2(1), 2014.

P. N. Sinambela. Kurikulum 2013 dan Implementasinya dalam Pembelajaran. Generasi Kampus, 6(2). 2017.

Puguh Suharsono, Metode Penelitian Kuantitatif untuk Bisnis: Pendekatan Filosofi dan Praktis, Jakarta, PT. Indeks, 2009.

Profil Pondok Pesantren Ma'arif Assunniyyah tahun 2018

Priyanto, Duwi, Mandiri Belajar SPSS, Mediakom, Yogyakarta, 2009.

Priyanto, Duwi, Mandiri Belajar Analisis Data dengan SPSS, Yogyakarta: Mediakom, 2013.

Poerwodarminto,WJS. Kamus Umum Bahasa Indonesia. Jakarta: Balai Pustaka, 1984.

Peraturan Pemerintah RI Nomor 32 Tahun 2013, Perubahan atas Peraturan Pemerintah Nomor 19 Tahun 2005 tentang Standar Nasional Pendidikan. 
Peraturan Menteri Pendidikan dan kebudayaan atau permendikbud Nomor 81A tahun 2013

Ronald C. Doll, Curriculum improvement: Decision making and process. Boston: Allyn and Bacon, 1970.

Rosyada, Dede. Paradigma Pendidikan Demokratis, sebuah Model Pelibatan Masyarakat dalam Penyelenggaraan Pendidikan. Jakarta: Prana Media, 2004.

Rizal, A. S. Transformasi corak edukasi dalam sistem pendidikan pesantren, dari pola tradisi ke pola modern. Jurnal pendidikan agama islam-ta'lim, 9(2), 95-112, 2011.

Slameto. Belajar dan Faktor-Faktor yang Mempengaruhinya. Jakarta: PT. Rineka Cipta, 2010.

S. Wekke, I. Pesantren dan pengembangan kurikulum kewirausahaan: Kajian pesantren roudahtul khuffadz sorong papua barat. INFERENSI: Jurnal Penelitian Sosial Keagamaan, 6(2), 205-226, 2012.

Slameto, Belajar dan Faktor-faktor yang Mempengaruhinya. Jakarta: Rineka Cipta. 1995.

Sani, R. A. Pembelajaran saintifik untuk implementasi kurikulum 2013, 2014.

Sinambela, P. N. Kurikulum 2013 dan Implementasinya dalam

Pembelajaran. Generasi

Kampus, 6(2), 2017.

Siregar, Syofian, Metode Penelitian Kuantitatif ; dilengkapi perbandingan perhitungan manual \& spss, edisi pertama. Jakarta: Kencana, 2015.

Sumardi, K. Potret Pendidikan Karakter di Pondok Pesantren Salafiah. Jurnal Pendidikan Karakter, (3), 2012.

Santosa P.B dan Ashari, Analisis Statistik dengan Microsoft Excel dan SPSS, Yogyakarta:

ANDI, 2005.

Sulistyorini, Muhammad Fathurrohman, Belajar dan Pembelajaran. Yogyakarta: Teras, 2012.

Sugiyono. Statistik Untuk Penelitian. Cet. Ke-XXI. Bandung: Alfabeta, 2012.
S., Mahfud Pengantar Psikologi Pedidikan. Surabaya: PT. Bina Ilmu, Cet. 4, 2001.

Slameto. Belajar dan Faktor-Faktor yang Mempengaruhinya. Jakarta: PT. Rineka Cipta, 2010.

Sukmadinata, Nana Syaodih. Pengembangan Kurikulum Teori dan Praktek. Bandung: Remaja Rosdakarya, 2005.

Sudjana, Nana. Pembinaan dan Pengembangan Kurikulum di Sekolah. Bandung: Sinar Baru Algesindo, 2005.

Sanjaya, Wina. Pembelajaran dalam Implementasi Kurikulum Berbasis Kompetensi. Jakarta: Prenada Media Group, 2005.

Sukmadinata, Nana Syaodih Pengendalian Mutu Sekolah Menengah. Bandung: Refika Aditama, 2003.

Sugiyono, Metode Penelitian Kuantitatif dan $R$ \& $D$, Bandung: Alfabeta, 2015.

Subandijah, Pengembangand an Inovasi Kurikulum. Jakarta: RajaGrafindo Persada, 1993.

Tim Pengembang MKDP Kurikulum dan Pembelajaran, Kurikulum dan Pembelajaran,. Jakarta: Rajawali Press, 2011.

Undang-undang Republik Indonesia No 20 Tahun 2003 tentang Sistem Pendidikan Nasional Pasal 1 ayat 19

Undang-undang Republik Indonesia nomor 20 tahun 2003 tentang Sistem Pendidikan Nasional, 2006.

Undang-undang RI No 20 Tahun 2003 tentang Sistem Pendidika Nasional Pasal 1 ayat 19 . 